\title{
Ondansetron and Granisetron in the Prophylaxis of Nausea and Emesis Induced by Cisplatin in Dogs
}

\author{
A. TOPAL, M. KAYA, N. GÜL \\ Department of Surgery, Faculty of Veterinary Medicine, Uludag University, Bursa, Turkey
}

Received March 15, 2004

Accepted March 3, 2005

\begin{abstract}
Topal A., M. Kaya, N. Gül: Ondansetron and Granisetron in the Prophylaxis of Nausea and Emesis Induced by Cisplatin in Dogs. Acta Vet. Brno 2005, 74: 111-116.

In the present study, the effects of 5-HT3 receptor antagonist granisetron and ondansetron on the acute phase of cisplatin-induced nausea and emesis were analyzed in dogs.

Fifteen healty dogs were used in this study. Cisplatin was administrated to all dogs to induce nausea and vomiting. All dogs that received cisplatin ( $3 \mathrm{mg} / \mathrm{kg} \mathrm{IV})$ were observed continuously for $8 \mathrm{~h}$. Five dogs administered only cisplatin acted as controls.

Cisplatin induced emetic response and nausea was detected in the controls. Ondansetron $(1 \mathrm{mg} / \mathrm{kg} \mathrm{IV})$ and granisetron $(60 \mu \mathrm{g} / \mathrm{kg} \mathrm{IV})$ were administered to the other animals $30 \mathrm{~min}$. before cisplatin administration. Although acute vomiting was significantly inhibited by ondansetron and granisetron, granisetron was found more effective on the nausea.

It was concluded that both ondansetron and granisetron are effective in the control of cisplatininduced vomiting in dogs, but granisetron is more effective than ondansetron in the inhibition of cisplatin-induced nausea in dogs.
\end{abstract}

5-HT3 receptor antagonist, vomiting, emetic response, canine

Highly emetogenic chemotheraputic agents, including cisplatin, are widely used in treating malignant disease with the most feared side effects occurring as nausea and vomiting (Laszlo and Lucas 1981; Jones et al.1991; Fukui et al. 1999; Tanihata et al. 2000; Goodin and Cunning ham 2002; Schnell 2003 ). Nausea and vomiting associated with chemotherapy can be classified as acute, delayed or anticipatory. Acute nausea and vomiting are defined as occurring within $24 \mathrm{~h}$ after chemotherapy and can be subdivided into acute (within $12 \mathrm{~h}$ ) and late-acute (12 - $24 \mathrm{~h}$ ) in humans (Schnell 2003).

Although the extent of nausea and vomiting varies by chemotherapeutic regimen, more than $90 \%$ of patients who receive $\geq 50 \mathrm{mg} / \mathrm{m}^{2}$ of cisplatin will vomit during the first $24 \mathrm{~h}$ after administration unless they receive effective prophylactic antiemetic therapy (Spector et al.1998; Schnell et al. 2003). In a previous experimental study (Fukui et al. 1999) it has been reported that cisplatin at a non-lethal dose $(3 \mathrm{mg} / \mathrm{kg}$, iv) induced acute phase vomiting in dogs, up to around $3 \mathrm{~h}$ after administration. This study also showed that cisplatin may not cause delayed emesis in dogs.

The 5-HT3 receptor antagonists have been regarded as the 'gold standard' in antiemetic therapy. Numerous studies investigating the use of ondansetron and granisetron have shown that when delivered intravenously both drugs are safe and highly effective in preventing nausea and vomiting induced by moderately high or highly emetogenic chemotherapy in humans (Spector et al. 1998; Fox-Geiman et al. 2001; Goodin and Cunningham 2002). Although both ondansetron and granisetron exhibit high binding affinities for the 5$\mathrm{HT}_{3}$ receptor, ondansetron also possesses weak affinity for $5-\mathrm{HT}_{1 \mathrm{~B}}, 5-\mathrm{HT}_{1 \mathrm{C}}, \alpha$-adrenergic and $\mu$-opioid receptors in humans. On the other hand, granisetron possesses significantly longer elimination half-lives than ondansetron (Goodin and Cunning ham 2002; Navari 2003; Schnell 2003).

Address for correspondence:

A. Topal

Department of Surgery

Faculty of Veterinary Medicine

Uludag University

16190 Bursa, TURKEY

Phone: +902242347655

Fax: + 902242346395

E-mail: atopal@uludag.edu.tr

http://www.vfu.cz/acta-vet/actavet.htm 
A number of studies on cisplatin-induced early phase emesis have been reported in dogs (Lelieveld et al.1987; Cohen et al.1989; Fukui et al.1999), cats (Smith et al. 1988), ferrets (Costal et al. 1987; Rudd and Naylor 1996) and pigeons (Preziosi et al. 1992; Tanihata et al. 2000). These studies suggested the important role of 5- $\mathrm{HT}_{3}$ in cisplatininduced early emesis in these species.

Effects of ondansetron on the cisplatin-induced nausea and vomiting was investigated in many experimental studies in dogs (Lelieveld et al.1987; Cohen et al.1989; Fukui et al.1999). Granisetron has not been used for prophylaxis regimens of nausea and vomiting induced by cisplatin in dogs so far.

This study was designed to compare the antiemetic and antinauseant efficacy of ondansetron and granisetron in dogs receiving highly emetogenic cisplatin chemotherapy. Although numerous reports in the literature state that the use of dexamethasone adds to the efficacy of $5-\mathrm{HT}_{3}$ receptor antagonists, corticosteroids were excluded from the study in order to demonstrate the antiemetic activity of a single intravenous dose of ondansetron and granisetron in dogs receiving cisplatin.

\begin{abstract}
Materials and Methods
Animals

In total, 15 adult dogs of two different breeds (12 Anatolian Shepherds and 3 Pointers) and sex (11 males, 4 females) were included in this study. Ages ranged from 1 to 4 years and body weights were between 8 and $15 \mathrm{~kg}$ (mean $11.7 \pm$ $2.5 \mathrm{~kg}$ ). Physical and haematological examinations had been performed two days before the study, and all dogs were found healty. The animals were fed with a commercial dog food (Medium Adult, Royal Canin, Denmark) and had free access to water. Food, but not water, was withheld for at least 12 hours before the start of the experiment. The study was performed with consent of the Ethical Commitee of the university.

Experimental periods

The dogs were divided into three groups (each of 5 animals) and all dogs were administrated cisplatin (Cisplatin-Teva, $\mathrm{Abic}^{\circledR}$, Netanya/Israel) at a dose of $3 \mathrm{mg} / \mathrm{kg}$ using slow intravenous administration schedule (approximately in $20 \mathrm{minutes}$ ). Cisplatin was prepared in normal saline at $70^{\circ} \mathrm{C}$ followed by gradual cooling to $40^{\circ} \mathrm{C}$ and administered immediately at a volume of $6 \mathrm{ml} / \mathrm{kg}$. In the control group (group I), no antiemetic drug was administered, but ondansetron (Zofran ${ }^{\circledR}$ injection, Glaxo, Italy) (1 mg/kg, iv.) and granisetron (Kytril ${ }^{\circledR}$ injection, Roche, Basel, Switzerland) $(60 \mu \mathrm{g} / \mathrm{kg}$, iv) were administered in groups II and III, respectively, 30 minutes before cisplatin administration.

The dosage of ondansetron was selected on the basis of previous studies in dogs, which demostrated that intravenous $(0.1-1 \mathrm{mg} / \mathrm{kg}$ ) administration was highly effective in inhibiting vomiting induced by cisplatin (S a grata et al. 1991; Eglen et al. 1993; Eglen et al. 1995; Fukui et al. 1999). Because any literature on the dosage of granisetron as an antiemetic in dogs could not be found, the dosage used in this study was determined on the basis of previous studies on humans (intravenously $40-60 \mu \mathrm{g} / \mathrm{kg}$ ).

Before cisplatin administration, saline solution $(0.9 \% \mathrm{NaCl})$ was administered intravenously to the dogs at 25 $\mathrm{ml} / \mathrm{kg} / \mathrm{h}$ during 3 hours in all groups. After antiemetic drugs were given saline administration was continued for one hour in all groups. At the same time, mannitol $(0.5 \mathrm{~g} / \mathrm{kg})$ and furosemide $(2 \mathrm{mg} / \mathrm{kg})$ were administered intravenously in all groups.

All animals treated with cisplatin were observed for survival once daily at least for 2 week after cisplatin administration.

Nausea and vomiting episodes were recorded remotely by video recorders for $8 \mathrm{~h}$ after cisplatin administration, and the number of episodes was counted for each respective observation period. Duration of emesis was calculated as the difference between the time at which the animal first vomited and that of the final vomiting episode during the observation period. Vomiting was defined as the expulsion of vomit or gastric juice from the stomach. At the same period, nausea was counted which the animals wanted the vomiting episodes but any vomit or gastric juice from the stomach. Vomiting and nausea episodes occurring less than $1 \mathrm{~min}$ apart were recorded as a single episode. No animal was used more than once.
\end{abstract}

Statistical Analysis

Data on the number, latency and duration of nausea and vomiting episodes induced by cisplatin were analyzed for differences from the control. The $t$-test was performed to compare the mean for the control group with that of the treatment groups. Dunnett's test was used to analyze significance; values of $p<0.05$ were regarded as statistically significant.

\title{
Results
}

Cisplatin-induced nausea and emesis without $5-\mathrm{HT}_{3}$ receptor antagonists Cisplatin injected intravenously at a dose of $3 \mathrm{mg} / \mathrm{kg}$ induced nausea and emesis in all dogs 
in control group with a mean latency of $1.4 \pm 1.2 \mathrm{~h}$ and $3.2 \pm 0.8 \mathrm{~h}$, respectively. With cisplatin alone, the mean nausea and emetic episodes were $6.2 \pm 3.1$ and $4.6 \pm 3.2$, respectively. The emetic response reached a peak at $2-3 \mathrm{~h}$, and decreased gradually within 8 hours after injection. Nausea began at the same time with vomiting episodes, but had longer duration than vomiting period (Tables 1 and 2). In the present study, emetic response within the $8 \mathrm{~h}$ period was called acute early emesis period.

Table 1. Effects of intravenous administration of ondansetron and granisetron on cisplatin-induced nausea in dogs

\begin{tabular}{|l|c|c|c|c|c|c|}
\hline Pretreatment & Dose & $\begin{array}{c}\text { No of dogs } \\
\text { nausea } / \text { tested }\end{array}$ & $\begin{array}{c}\text { No. of nausea } \\
\text { episodes } \\
(\text { mean } \pm \text { SE) }\end{array}$ & $\begin{array}{c}\text { Inhibitory } \\
(\%)\end{array}$ & $\begin{array}{c}\text { Latency periods } \\
(\mathrm{h}, \text { mean } \pm \text { SE) }\end{array}$ & $\begin{array}{c}\text { Duration } \\
(\mathrm{h}, \text { mean } \pm \text { SE) }\end{array}$ \\
\hline None & - & $5 / 5$ & $6.2 \pm 3.1$ & - & $1.4 \pm 1.2$ & $3.1 \pm 2.4$ \\
\hline Ondansetron & $1 \mathrm{mg} / \mathrm{kg} \mathrm{IV}$ & $3 / 5$ & $2.6 \pm 1.2^{\mathrm{a}}$ & 75 & $4.4 \pm 2.0^{\mathrm{a}}$ & $0.7 \pm 0.4^{\mathrm{a}}$ \\
\hline Granisetron & $60 \mu \mathrm{g} / \mathrm{kg} \mathrm{IV}$ & $0 / 5$ & - & 100 & - & - \\
\hline
\end{tabular}

Table 2. Effects of intravenous administration of ondansetron and granisetron on cisplatin-induced vomiting in dogs

\begin{tabular}{|l|c|c|c|c|c|c|}
\hline Pretreatment & Dose & $\begin{array}{c}\text { No of dogs } \\
\text { vomiting } \\
/ \text { tested }\end{array}$ & $\begin{array}{c}\text { No. of vomiting } \\
\text { episodes } \\
(\text { mean } \pm \text { SE) }\end{array}$ & $\begin{array}{c}\text { Inhibitory } \\
(\%)\end{array}$ & $\begin{array}{c}\text { Latency periods } \\
\text { (h, mean } \pm \text { SE) }\end{array}$ & $\begin{array}{c}\text { Duration } \\
(\mathrm{h}, \text { mean } \pm \text { SE) }\end{array}$ \\
\hline None & - & $5 / 5$ & $4.6 \pm 3.2$ & - & $3.2 \pm 0.8$ & $0.8 \pm 0.5$ \\
\hline Ondansetron & $1 \mathrm{mg} / \mathrm{kg} \mathrm{IV}$ & $0 / 5$ & - & 100 & - & - \\
\hline Granisetron & $60 \mu \mathrm{g} / \mathrm{kg} \mathrm{IV}$ & $0 / 5$ & - & 100 & - & - \\
\hline
\end{tabular}

All animals were treated intravenously with cisplatin at a dose of $3 \mathrm{mg} / \mathrm{kg}$. In the control group, no antiemetic drug was administered before cisplatin. Ondansetron and granisetron were administreted intravenously $30 \mathrm{~min}$ before administration of cisplatin. Compared with control, ${ }^{\mathrm{a}} p<0.01$.

Antiemetic effects of $5-\mathrm{HT}_{3}$ receptor antagonists on cisplatin-induced nausea and emesis

Ondansetron completely reduced the cisplatin-induced early emetic responses during the 8 -h observation period. But three of the five dogs treated with ondansetron exhibited many nausea episodes after cisplatin administration.

Granisetron completely suppressed the cisplatin-induced both emetic and nauseous responses during the $8 \mathrm{~h}$ observation period. Vomiting assesments were not significantly different between groups II and III at any time points.

\section{Discussion}

Most studies have used cisplatin as the anticancer agent of choice in their models for the induction of emesis. It is generally accepted that stimulation of the abdominal vagal afferent nerves via the $5-\mathrm{HT}_{3}$ receptor is important to trigger acute emesis induced by cisplatin. Animal models of chemotherapy-induced acute emesis, successfully predicted the clinical efficacy of the $5-\mathrm{HT}_{3}$ receptor antagonists for the control of vomiting. Indeed, the cisplatininduced acute emetic model in dogs and ferrets have been extensively used to identify the antiemetic potential of novel drug therapies (Y a makuni et al. 2000).

In the present study, cisplatin at a non-lethal dose $(3 \mathrm{mg} / \mathrm{kg}$, iv $)$ induced acute phase nausea and emetic episodes, up to $1.4 \pm 1.2 \mathrm{~h}$ and $3.2 \pm 0.8 \mathrm{~h}$ after administration, respectively, in the control group. On the other hand, delayed emetic response was observed after administration of cisplatin. 
In this study, ondansetron and granisetron were used for preventing acute phase nausea and vomiting induced by cisplatin. Although effects of ondansetron on the cisplatin-induced nausea and vomiting were investigated in many experimental studies (Lelieveld et al.1987; Cohen et al.1989; Fukui et al.1999), there are only a few studies on granisetron. In these studies, granisetron was used in different dosages with different aims. It was administered intravenously $(0.316 \mathrm{mg} / \mathrm{kg})$ for determination of plasma peptide YY levels with cisplatininduced emesis in dogs (Perry et al.1994); administered intravenously $(0.5 \mathrm{mg} / \mathrm{kg}$ ) for comparison of antiemetic efficacy of ginger (Zingiber officinale) against cisplatin-induced emesis in dogs (Sharma et al. 1997); administered intravenously $(0,25-10 \mathrm{mg} / \mathrm{kg}$ ) to investigate, the disposition and metabolic fate of granisetron had studied in rats, dogs, and male human volunteer (Clarke et al. 1994). But, these dosages were higher (almost 10 - 200 times) than doses in humans for prophylaxis regimens of nausea and vomiting induced by cisplatin.

The dosage of granisetron, administered in this study, were similar to doses used in humans $(10-60 \mu \mathrm{g} / \mathrm{kg}$, iv) (Upward et al.1990; Spector et al. 1998; Abraham et al. 2000; Goodin and Cunningham 2002; Minami 2003;).

In the present study, we administered ondansetron $(1 \mathrm{mg} / \mathrm{kg}$, iv) or granisetron $(60 \mu \mathrm{g} / \mathrm{kg}$, iv) for preventing acute phase nausea and vomiting induced by cisplatin. It was demonstrated that ondansetron and granisetron totally inhibited the acute vomiting induced by cisplatin.

Similarly, it was reported that ondansetron reduced the number of vomiting episodes induced by cisplatin by $91 \%$ in dogs (Fukui et al.1999). According to the results of that study, ondansetron caused decreases on emetic responses following cisplatin administration from $2.3 \pm 0.3$ to $16.0 \pm 1.3$ in dogs. In our study, emetic episodes were not observed. However, three of the five dogs treated with ondansetron exhibited nausea episodes after cisplatin administration.

Sharma et al. (1997) reported that granisetron reduced the number of vomiting episodes induced by cisplatin in dogs. They demonstrated that two of the five dogs treated with granisetron exhibited emetic episodes and granisetron reduced emetic episodes induced by cisplatin in dogs from $0.8 \pm 0.4$ to $13.7 \pm 2.2$. These results are similar to ours.

As described above, acute vomiting induced by cisplatin was completely inhibited by intravenous administration of ondansetron and granisetron. These results match those of studies with human beings receiving cisplatin (Upward et.al.1990; Spector et al. 1998; Fox-Geiman et al. 2001; Goodin and Cunningham 2002; Minami 2003) and the clinical profiles of these agents in the treatment of cisplatin-induced emesis (Goodin and Cunningham 2002; Navari 2003; Schnell 2003). Moreover, granisetron was more effective than ondansetron in reducing the nausea episodes induced by cisplatin.

These effects of granisetron can be related to be more specific for $5-\mathrm{HT}_{3}$ receptor than those of ondansetron, suggesting that both granisetron and ondansetron exhibit high binding affinities for $5-\mathrm{HT}_{3}$ receptor and granisetron is more specific for this receptor than ondansetron.

In conclusion, intravenous administration of cisplatin at a non-lethal dose caused acute nausea and emesis in dogs. The acute vomiting induced by cisplatin was completely inhibited by intravenous administration of ondansetron and granisetron. But, three of the five dogs exhibited nausea episodes after cisplatin administration in ondansetron group.

Also, granisetron completely inhibited vomiting episodes after cisplatin administration. Furthermore, no animal treated with granisetron did exhibit nausea episodes after cisplatin administration. In this study, high successful conclusion of antiemetic drugs may be also related to full supportive therapy, such as long period fluid administration. In our study exhibited that ondansetron and granisetron inhibited vomiting episode induced by cisplatin by $100 \%$ in dogs. 


\section{Ondansetron a granisetron $v$ prevenci nausey a zvracení vyvolaného cisplatinou u psů}

V této studii byl zkoumán účinek granisetronu a ondansetronu, antagonistů 5-HT ${ }_{3}$, v akutní fázi nausey a zvracení vyvolaného cisplatinou u psů. V této studii bylo využito 15 zdravých psů. Cisplatina byla aplikována všem psům k vyvolání nausey a zvracení. Všichni psi, kterým byla cisplatina aplikována $\left(3 \mathrm{mg} \cdot \mathrm{kg}^{-1} \mathrm{i} . \mathrm{v}\right.$.), byli nepřetržitě pozorování po dobu 8 hodin. Pěti psům byla aplikována pouze cisplatina a sloužili jako kontrolní skupina. Cisplatina vyvolala u kontrolní skupiny zvracení a nauseu. Ostatní zvířata byla 30 minut před podáním cisplatiny ošetřena ondansetronem $\left(1 \mathrm{mg} \cdot \mathrm{kg}^{-1}\right.$ i.v. $)$ a granisetronem $\left(60 \mu \mathrm{g} \cdot \mathrm{kg}^{-1}\right.$ i.v. $)$. Ačkoliv jak ondansetron tak i granisetron signifikantně potlačily akutní zvracení, vůči nausei se ukázal jako účinnější granisetron. Došlo se k závěru, že u psů je jak ondansetron tak i granisetron učinný při kontrole cisplatinou vyvolaného zvracení, nicméně granisetron je účinnější než ondansetron při potlačovaní cisplatinou vyvolané nausey.

\section{References}

ABRAHAM, A, SRIDAR, N, VEERANJANEYULU, A 2000: Cancer chemotherapy and radiation induced emesis: current and future therapeutic approaches. Indian J Pharmacol 32: 256-268

CLARKE, SE, AUSTIN, NE, BLOOMER, JC, HADDOCK, RE, HIGHAM, FC, HOLL, FJ, NASH, M, SHARDLOW, PC, TASKER, TC, WOODS, FR 1994: Metabolism and disposition of 14C-granisetron in rats, dogs, and man after intravenous and oral dosing. Xenobiotica 24: 1119-1131

COHEN, ML, BLOOMQUIST, W, GIDDA, JS, LACEFIELD, W 1989: Comparison of the 5-HT 3 receptor antagonist properties of ICS 205-930, GR38032F and zacopride. J Pharmacol Exp Ther 248: 197-201

COSTALL, B, DOMENEY AM, NAYLOR, RJ, TATTERSALL, FD 1987: Emesis induced by cisplatin in the ferret as a model for the detection of antiemetic drugs. Neuropharmacology 26: 1321-1326

EGLEN, RM, LEE, CH, SMITH, WL, JOHNSON, LG, WHITING, RL, HEGDE, SS 1993: RS 42358-197, a novel and potent 5- $\mathrm{HT}_{3}$ receptor antagonist, in vitro and in vivo. $\mathrm{J}$ Pharmacol Exp Ther 266: 535-543

EGLEN, RM, LEE, CH, SMITH, WL, JOHNSON, LG, CLARK, R, WHITING, RL, HEGDE, SS 1995: Pharmacological characterization of RS 25259-197, a novel and selective 5- $\mathrm{HT}_{3}$ receptor antagonist, in vivo. Brit J Pharmacol 114: 860-866

FUKUI, H, YAMAMOTO, M 1999: Methotrexate produces delayed emesis in dogs: A potential model of delayed emesis induced by chemotherapy. Eur J Pharmacol 372: 261-267

FOX-GEIMAN, MP, FISHER, SG, KILEY, K, GONZALEZ, DF, PORTER, N, STIFF, P 2001: Double-blind comparative trial of oral ondansetron versus oral granisetron versus iv ondansetron in the prevention of nausea and vomiting associated with highly emetogenic preparative regimens prior to stem cell transplantation. Biol Blood Marrow Transplant 7: 596-603

GOODIN, S, CUNNINGHAM, R 2002: 5- $\mathrm{HT}_{3}$ receptor antagonist for the treatment of nausea and vomiting. The Oncologist 7: 424-436

JONES, AL, HILL, AS, SOUKOP, M, HUTCHEON, AW, CASSIDY, J 1991: Comparison of dexamethasone and ondansetron in the prophylaxis of emesis induced by moderately emetogenic chemotherapy. Lancet 338: 483490

LASZLO, J, LUCAS, VS 1981: Emesis as a critical problem in chemotherapy. New Engl J Med 305: $948-949$

LELIEVELD, P, VAN DER VIJGH, WJF, VAN VELZEN, D 1987: Preclinical toxicology of platinum and analogues in dogs. Eur J Cancer Clin Oncol 23: 1147-1154

MINAMI, M 2003: Granisetron: is there a dose-response effect on nausea and vomiting? Cancer Chemother Pharmacol 52: 89-98

NAVARI, RM 2003: Pathogenesis-based treatment of chemotherapy-induced nausea and vomiting-two new agents. J Support Oncol 1: 89-103

PERRY, MR, RHEE, J, SMITH, WL 1994: Plasma levels of peptide YY correlate with cisplatin-induced emesis in dogs. J Pharm Pharmacol 46: 553-557

PREZIOSI, P, D’AMATO, M, DEL CARMINE, R, MARTIRE, M, POZZOLI, G, NAVARA, P 1992: The effects of 5- $\mathrm{HT}_{3}$ reseptor antagonists on cisplatin induced emesis in the pigeon. Eur J Pharmacol 221: 343-350

RUDD, JA, NAYLOR, RJ 1996: An interaction of ondansetron and dexamethasone antagonizing cisplatin-induced acute and delayed emesis in the ferrets. Brit J Pharmacol 118: 209-214

SAGRATA A, TURCONI, M, BONALI, P, SCHIANTARELLI, P, MICHELETTI, R, MONTAGNA, E, NICOLA, M, ALGATE, DR, RIMOLDI, EM, DONETTI, A 1991: Antiemetic activity of the new 5-HT receptor antagonist DAU6215 in animal models of cancer chemotherapy and radiation. Cancer Chemother Pharmacol 28: 470-474

SCHNELL, FM, 2003: Chemotherapy induced nausea and vomiting. The Oncologist 8: 187-198 
SHARMA, SS, KOCHUPILLAI, V, GUPTA, SK, SETH, SD, GUPTA, YK 1997: Antiemetic efficacy of ginger (Zingiber officinale) aganist cisplatin induced emesis in dogs. J Ethnopharmacol 57: 93-96

SMITH, WL, CALLAHAM, EM, ALPHIN, RS 1998: The emetic activity of centrally administered cisplatin in cats and its antagonism by zacopride. J Pharm Pharmacol 40: 142-143

SPECTOR, JI, LESTER, EP, CHEVLEN, EM 1998: A comparison of oral ondansetron and intravenous granisetron for the prevention of nausea and emesis accociated with cisplatin based chemotherapy. The Oncologist 3: 432-438

TANIHATA, S, IGARASHI, H, SUZUKI, M, UCHIYAMA, T 2000: Cisplatin-induced early and delayed emesis in the pigeon. Brit J Pharmacol 130: 132-138

UPWARD, JW, ARNOLD, BD, LINK, C, PIERCE, DM, ALLEN, A, TASKER, TC 1990: The clinical pharmacology of granisetron (BRL 43694), a novel specific 5-HT3 antagonist. Eur J Cancer 26: 12-15

YAMAKUNI, H, SAWAI, H, MAEDA, Y, IMAZUMI, K, SAKUMA, H, MATSUO, M, MUTOH, S, SEKI, J 2000: Probable involvement of 5-HT receptor in methotrexate induced delayed emesis in dogs. J Pharmacol Exp Ther 292: 1002-1007 